\title{
The crisis that looks like no other: reflections on the "corona-crisis"
}

\author{
José Álvaro de Lima Cardoso ${ }^{1}$ \\ https://orcid.org/0000-0001-5962-2056 \\ ${ }^{1}$ Inter-union Department of Statistics and Socio-Economic Studies, Office of Santa Catarina, Florianópolis, SC, Brazil
}

\section{The crisis that looks like no other: reflections on the "corona-crisis"}

Abstract: The objective of this text is to deepen the debate about a global economic crisis, which was already forming, but immensely catalyzed by the Covid-19 crisis. The analysis, comparison of data from authorized institutions, seeks, based on the indicators of the global crisis, to always do or contradict Brazil. One of the conclusions highlighted in the text is the current crisis, also called "Corona Crisis", is one of the most relevant in history and has already overcome the Great Depression of 1929, mainly in the speed with which the world economy is deteriorating. In this crisis, the worsening of macroeconomic and social indicators, which developed in the 1930s in three years, occurred in three weeks. The article also concludes that Brazil faces a sum of simultaneous crises, which influence each other.

Keywords: Crisis. Economical. International. Unemployment. Depression.

Received 08.05.2020. Approved 15.06.2020. Revised 02.07.2020.

(C) The Author(s). 2020 Open Access This article is distributed under the terms of the Creative Commons Attribution-NonCommercial 4.0 International License (http://creativecommons.org/licenses/by-nc/4.0/), which permits use, distribution, and reproduction in any medium, since it's for non-commercial purposes, and provided you give appropriate credit to the original author(s) and the source, provide a link to the Creative Commons license, and indicate if changes were made. 


\section{Introduction}

The following text initially presents an analysis of the development of crises (economic and health) in the different countries of the world, aiming to understand the seriousness of the problem and the way in which the various governments are facing it. Today, the world is going through what some economists have called the "corona-crisis". The ongoing brutal economic crisis, comparable to the Great Depression of 1929, was not caused, but accelerated by the Covid-19 pandemic. This is already the biggest global economic and financial crisis since the 1930s, and was called by the International Monetary Fund (IMF) a "great lockdown". If this crisis has not yet surpassed that of 1929 (it is difficult to be categorical, given the scarcity of comparable indicators between one crisis and another), judging by the speed of events, it will overcome it.

From a medical point of view, this crisis is very serious. A group of researchers from the Harvard University School of Public Health ${ }^{1}$ came to the conclusion that efforts at social distancing to prevent hospital collapse in the face of the covid-19 pandemic may be necessary, at least intermittently, by 2022 . Worldwide, the pandemic is far from being "democratic", as some would like. It is obvious that those who die are the poorest. The middle classes are being affected, but the economically vulnerable groups are the most impacted and account for the bulk of deaths. Estimate that a quarter of the world population lives in slums. In Brazil there are 13.6 million in this condition. This means that, often, eight or nine people huddle together in one or two rooms. In this condition it is impossible to avoid the crowding of people, going out into the street is inevitable.

From this perspective of what happens in the world, we try to analyze the situation in Brazil a little, which is going through a dramatic political and economic crisis. The current Brazilian crisis is very serious, because it summarizes:

1. unusual world economic crisis;

2. dramatic crisis in the Brazilian economy: the country has been experiencing three years of stagnation, after two years of brutal recession (2015/2016). Recession much worse by the 2016 coup d'état;

3. a pandemic that is already the most serious in the last century;

4. acute political crisis, with great polarization in society.

This conjunction of crises occurs at a time when Brazil has the worst government in history: the most surrendered and the most servile to gigantic geopolitical interests. A government that intends to make the country unfeasible as a nation and that plans to completely destroy Brazilian sovereignty, hand over the Amazon, our maritime border. That is destroying national science, scrapping federal universities and Federal Institutes, cut the scientific budget by more than $60 \%$. The list of atrocities committed since the 2016 coup, which was greatly increased in this government, is very long.

As a result of this macabre combination, Brazil is the most problematic case in the world, in terms of coping with the pandemic and is fast becoming the global epicenter of the disease. It is that the control of the pandemic presupposes focus, strategy and planning, in addition to a commitment to the well-being of the population, elements absolutely foreign to this government, in all areas.

In the text below, we initially approach the economic crisis in the world, seeking to analyze how the different countries have tried to face them, verifying the differences and similarities in the approach to the problem. In a second moment, we briefly analyze the situation of the American economy, due to the weight it has in the world economy and the fact that, as the head of the imperialist countries, its actions always have great worldwide repercussions.

Subsequently, we bring some elements that illustrate the seriousness of the crisis in the world and the coping options adopted in different countries. Then, we analyze the Brazilian case, which, at the moment, faces what can be called "perfect storm". Finally, as concluding notes, we seek to reflect on some general trends in the world, in economic and political aspects.

\section{Economic crisis spread worldwide}

The $\mathrm{IMF}^{2}$ forecast is that the Gross Domestic Product (GDP) of the global economy will fall by $3 \%$ in 2020. For comparative purposes, the recession of the 2008 global financial crisis registered a decline in GDP of $-0.1 \%$ in 2009 . With these falling numbers of the global product, one can imagine what this will mean in terms of rising poverty and hunger in the world.

In the IMF forecast, international trade will show a drop in volume of $-11 \%$ in 2020 . The report also estimates that of the 189 countries in the world 170 will have a drop in the variation of GDP, which reveals the scope of the current crisis. Commodity prices have dropped dramatically due to the retraction in demand. The biggest setback is due to oil, which had an unprecedented drop in consumption: the WTI barrel, a 
reference for the American market, has shown a negative price. Experts estimate that the price of oil will drop by more than $40 \%$ in 2020 , due to low global demand.

Obviously, all these projections must be looked at with caution, as the performance of the global economy will depend on the interaction of factors that are difficult to predict, such as the evolution of the pandemic, the intensity and duration of the isolation measures, the size of the supply shock due the interruption of production chains, the impact of the financial shock, etc. This means that the performance of the global economy may be even worse than what has been projected by world institutions, such as the IMF and the World Bank.

The IMF forecast is that the group of advanced economies will be the main responsible for the contraction of the global economy this year. Possibly due to the fact that the health crisis had its successive epicenter in the richest economies on the planet, first reaching China, later Europe and, in April, the United States ${ }^{3}$. This group of rich countries should have a $6.1 \%$ drop in GDP, in other words, it should fall in a double percentage in relation to the world average. The greatest decline in GDP is likely to be registered in the Euro Area (-7.5\%), due to the seriousness of the epidemic in Italy and Spain and, to a lesser extent, in France and Germany. Intense decreases in economic performance are also expected for the United Kingdom (-6.5\%), the United States (-5.9\%) and Japan $(-5.2 \%)$, countries that make up the world imperialist center. In a not so adverse situation are the countries that have had the most success in containing the covi-19, such as China, Singapore, Hong Kong, South Korea, Vietnam.

In underdeveloped countries, crises are diverse and take on specific shapes:

1. a health shock in the face of precarious, or non-existent, public health systems;

2. brutal economic shock, with collapse of external and internal demand;

3. fall in commodity prices;

4. strong exchange rate depreciations.

The above factors, serious in themselves, potentiate each other. The IMF forecast is for a $1 \%$ drop in the average GDP variation in the group of underdeveloped economies (which the Fund calls emerging and developing countries). This result, however, hides strong heterogeneity. The so-called emerging Asia should only decelerate, maintaining a positive performance $(+1 \%$ in the year), mainly due to China $(+1.2 \%)$ and India $(+1.9 \%)$. But other regions, such as Latin America and emerging Europe, will see a sharp drop in their GDP, possibly above 5\%. For Brazil, the IMF and World Bank forecast is for a decrease of at least $5 \%$. It will be a performance below that of Latin America, for which the economic analysis agencies are forecasting a 4.6\% contraction (World Bank).

The severity of the crisis can best be assessed using indicators from Germany, Europe's largest economy. The country's economy was already in a kind of "limbo". In 2019, for example, it had the worst growth in the last 6 years $(0.6 \%)$. But the pandemic caused by the New coronavirus has put this economy in an even more precarious situation, possibly leading to the most serious post-World War II recession. Unemployment, of 5.8\%, increased 13.2\% in April, the highest one-month high since 1991. It is the first time in the post-war that the unemployment rate has risen during the month of April, which marks the beginning in the Northern Hemisphere, during which the labor market is expected to warm up.

The drop in German GDP, according to the government forecast, is expected to reach 6.3\% this year, the biggest since these calculations started to be released in 1970. Another indicator of the seriousness of the German situation is the numbers of industrial production, which have been falling since 2019, but it is a problem that has now become more acute. In March, Germany suffered a 9.2\% historical reduction in industrial production, compared to February. According to Destatis, the country's statistics agency, it was the biggest drop seen since the beginning of the construction of the database, in January 1991. The drop was not only greater because the construction sector showed an increase in production of $1.8 \%$ in the month. Compared with March 2019, German industrial production fell by $11.6 \%$.

The crisis in Europe's largest economy had an immediate effect on the entire Eurozone. For 2020, GDP contraction is expected to reach $7.5 \%$ for all 19 countries in the Euro zone. In this context, unemployment in the Eurozone started to skyrocket, 7.4\% (almost 12 million unemployed) in March. The champion countries of unemployment in Europe are Greece with the highest index 16.4\% (data from January), followed by Spain, with $14.5 \%$ also in March. In addition to the brutal rise in unemployment, the deterioration of the labor market is compounded by increased informality across the region.

The forecast is that only emerging countries in Asia will see positive growth of $+1 \%$, including China, which can expect a $1.2 \%$ increase in their GDP, and India, whose expected growth is $1.9 \%$. The IMF predicts a 1.6\% drop in GDP in sub-Saharan Africa (region south of the Sahara), which is expected to experience a $1.6 \%$ decrease, with the risk of a food crisis. Everything indicates that there will be a brutal increase in hunger in the region. Worldwide, the crisis has highlighted a series of inequalities, now increasing: income, education, access to digital equipment, access to the Internet, others. In addition to inequalities linked to heritage, such as access to housing, which is fundamental in times of social isolation. 
From what is observed in terms of the development of the crisis, the tendency is for the pandemic to worsen the situation of the working class and intensify the class struggle. Thus, it is an illusion to think that class contradictions, and between imperialist and underdeveloped countries, will subside because of the pandemic. Poverty and job insecurity have intensified even further as a result of the crisis. In each capitalist country, the bourgeoisie seeks to maneuver the crisis and its consequences, based on its class interests. The exits are never neutral, but shaped by the interests of those who hold power.

The economic crisis process is going much deeper and faster than that observed in the crisis of 2008 and the Great Depression of 1929. The economist Noriel Roubini - whose analyzes that were previously considered pessimistic, are now seen as realistic - notes that in those two major crises stock exchanges fell by $50 \%$ or more, credit markets froze, major bankruptcies happened, unemployment rates rose above 10\% and GDP shrank at an annualized rate of $10 \%$ or more. But all of these phenomena took place in three years or more. In the current crisis, says Roubini, all this materialized in three weeks. In three weeks, a month, the elements that make up the so-called aggregate demand (consumption, capital expenditure, exports) are in free fall, as never seen before. It is as if we had a recurrence of a serious disease, whose impacts on the organism happen, in the recurrence, in a much faster way. The information is doubly negative: the disease returns and the speed with which it spreads. Obviously part of this speed of propagation of the crisis is related to the globalization of the economy, and of information, especially in relation to 1929. But in 2007 the economy was as globalized as today. The speed with which information circulates in the markets today, is similar to that existing in 2007/2008.

The severity of the crisis can also be measured on the basis of what is happening to the Chinese economy, the engine of the world economy in recent years: contraction of $6.8 \%$ of GDP in the first quarter of 2020, compared to the same period in the previous year. Worst single-quarter drop China has recorded since it began publishing these figures in 1992. The growth forecast (1.2\% for the year, as we have seen), represents the country's worst annual GDP performance since the recession of 1976, when the death of Communist Party leader Mao Zedong ended a decade-long social and economic turmoil (44 years ago). The reasoning is elementary: if China, the most dynamic economy in the world, a country that gave a real lesson in how to face a plague, had the worst quarter in history, and that has a national development project, what can happen with the Brazil, which is the worst case of coping with the disease in the world?

\section{Crisis in the American economy}

The intensity of economic problems in the United States, the epicenter of global capitalism, is a thermometer of the seriousness of the current crisis. The IMF estimates that the North American economy will present a $5.9 \%$ retraction in its Gross Domestic Product (GDP), an unprecedented fact. This result interrupts 10 years of growth, a cycle that started in 2010, following the great global recession that occurred in the period 2007-2009. Growth period, moreover, considered unusual not only for its duration, but also for the reasonable rate of growth (2\% per year, on average).

The sharp and sharp drop in GDP has led to a dramatic rise in unemployment in the largest economy on the planet. The country recorded an unemployment rate of $14.7 \%$ in April, the highest in more than 70 years and the highest unemployment rate since records began to be made in 1948. Still in February this year, unemployment reached the lowest percentage in history, 3.5\%, which shows the worsening of the problem in such a short time, as a result of the pandemic. According to the United States Department of Employment, up to 20.5 million people lost their jobs last April.

According to official information, the current crisis destroyed, in the first month, all jobs generated after the great economic crisis of 2007/2009. For comparison, during that crisis, the United States would have reached an unemployment peak of around $10 \%$ in October 2009. During the entire period of the crisis, more than 8 million jobs would have been destroyed, against more than 20 million in a month, in this crisis. The brutal unemployment rate in the United States, is aggravated by the immense inequality, which emerges in the unemployment indicator: for the general index, which in itself is explosive, it still varies considerably between ethnic groups. Among whites, unemployment was 14.2\% in April, for African Americans it was 16.7\%, and among Hispanics reached $18.9 \%$.

Even taking advantage of all the advantages of being the main imperialist country on earth, the USA faces great internal contradictions, because its development model generates great social inequality. At least since the government of Ronald Reagan (1981/1989), the American welfare state, which was already weak, has been gradually destroyed. It is estimated that there are currently more than 40 million poor people in the USA. About $40 \%$ of Americans complain that they are unable to cover unexpected expenses for emergencies, which exceed $\$ 400^{4}$ The fact that the United States has such a large number in poverty is a real time bomb. A 
workers' uprising within the richest imperialist country in the world would have a political, economic and social effect, simply unpredictable. Risk that must have influenced the US decision, about a decade ago, to "retake" the governments of Latin America to their area of influence.

\section{The seriousness of the crisis and the actions to confront it worldwide}

In the capitalist system, the labor market functions as an "adjustment variable" for the business community. At time $\mathrm{H}$, when the crisis gets worse, businessmen dismiss the workers without further ado. Hence the class struggle over labor law. Entrepreneurs hate labor market regulation because, when the crisis arises, it means an obstacle to adjusting costs. The existence of a job in the capitalist system is only justified if the capitalist can appropriate a part of the value produced by the worker. If this is not the logic, the system would not be capitalist. In the case of Brazil, an underdeveloped and dependent country, there has never been a culture of job preservation (rare, indeed, even in the central capitalist countries), which minimally guaranteed the well-being of people and the domestic consumer market.

When the economic crisis worsens, entrepreneurs have a hierarchy of strategies to face the problem, in which the sacrifice of employment is the first to be used. The turnover rate in Brazil, even, always at heights, reveals how layoffs have always been the bosses' preferred strategy at the time of the crisis brought on by the crisis. If the turnover rate is monstrous, to the point that in some categories $100 \%$ of workers work in a single year, it is because it is not costly to fire, as the bosses have always claimed in Brazil.

The pandemic did not cause the economic crisis, it only accelerated it. Some analyzes give the impression that the economy was in a brigadier sky, with a strong wind, when the pandemic came and caused the crisis. The fact is that the tsunami had been arming for a long time. The epidemic only anticipated the worsening of the crisis. The contradictions that led to the 2007/2008 crisis (caused by the financialization of the economy) remain, have not been resolved. On the contrary, some have been aggravated. One would expect that a new crisis would come sooner or later. The impact of the two crises brought together, on the economy and politics in the world is being and will be even more dramatic. As Covid-19 is an unknown disease, for which there is still no vaccine (it will take a few months, perhaps years), the depth and extent of the crisis ca nnot yet be estimated.

Regarding the post-pandemic situation, there are a range of possibilities. We have seen some extremely optimistic analyzes, about post-Covid-19: that the world will be more harmonious, that the fear of the disease will bring people together, that the world will be more sympathetic. It is a very optimistic approach, to say the least. It will not be a disease that will end the capital versus labor conflict in the world. Depending on what happens, things can get worse. For example, the Brazilian government is taking advantage of the pandemic to transfer the burden of the crisis to the worker, through numerous measures such as MP 937 and MP 905. In this context, when the pandemic ends, the worker will be poorer, the income pattern and employment, which was already in a process of deterioration, will be at another level.

If neoliberal policies were fundamental to transfer, at least in part, the crisis from the center of the system to the capitalist periphery, at the same time they destroyed the already precarious public policies for serving the population, starting with the public health and education systems. The United States faces a chaotic situation, quickly becoming the epicenter of the pandemic in the world, with more than 105,000 deaths and 1.8 million people infected by Covid-19, as of 30.05.20. On the other hand, the Chinese state has put its resources and its organizing force in response to the pandemic. The structuring of patient care carried out in an extremely agile way, the organization of the population, the adaptation of industrial production to the needs of fighting the disease, the construction of hospitals in record time, the availability of a large number of tests - actions basically taken to carried out by the State - referred for a quick control of the disease. However influential it may be by the hegemonic media, a part of people perceives these differences ${ }^{5}$.

In order to feel the drama of the crisis, it is didactic to pay attention to what the rich countries have been doing to face it. The measures that these countries, which normally have privileged information, are taking, should serve as a warning about the seriousness of the crisis. Germany, for example, the "homeland of fiscal austerity" (4th GDP in the world), is putting 35\% of its GDP (4th in the world) in fighting crises. The United States approved the most important economic plan in the history of the world economy. The forecast is for an initial expenditure of almost two trillion dollars, equivalent to about $\mathrm{R} \$ 10$ trillion (for comparison, the Brazilian GDP last year was R \$ 7.3 trillion). They will put another two trillion dollars at the end of the pandemic. This fable of money, an antidote against the economic crisis and the pandemic, foresees massive injections in companies and even in the pockets of citizens.

The bulk of these investments in rich countries are being made in companies. States are commanded by the bourgeoisies of each country. There, as here, governments want to solve the problem of the bourgeoisie. Of 
course, there are differences in the treatment of workers there and here, because Brazil is an underdeveloped and dependent country. The United States is the leading imperialist country on the globe, draining resources from around the world to guarantee its interests. He even finished coordinating a coup in Brazil to take the presalt and other wealth. As in several Latin American countries. So, it has many more resources, including to put money directly in the pocket of the majority of the population. Direct transfers of money, which reached the majority of US citizens, are $\$ 1,200$ per adult and $\$ 500$ per minor. Such direct aid to citizens could reach $\$ 500$ billion. The plan also includes a $\$ 367$ billion credit line for small and medium-sized businesses, and a $\$ 500$ billion fund for industries, cities and states. The dismissed workers will receive unemployment insurance for four months, in the amount usually paid in their state, plus an extra $\$ 600$.

As in the United States, the European Union (EU) made a package of economic measures of 500 billion euros (2.8 trillion reais, $40 \%$ of Brazilian GDP) to support countries, companies and workers during the pandemic caused by the coronavirus. The package of measures adopted consists of three pillars: a credit line from the European Stability Mechanism, the eurozone rescue fund, with EUR 240 billion in loans; a European Investment Bank guarantee fund with up to 200 billion euros in loans to companies; and a temporary fund with 100 billion euros to help pay workers' wages and prevent layoffs. (That is, at best, only $20 \%$ of the value goes to workers).

Much of the economies already needed vigorous fiscal policies, even before the coronavirus crisis. Italy, for example, the country hardest hit by the outbreak in Europe, was almost in recession before the coronavirus. This is also the case in Germany, considered the engine of the European economy, which grew by a mere $0.6 \%$ in 2019 , a notable deceleration in relation to $2017(2.5 \%)$ and 2018 (1.5\%). This plan to help companies in Germany is more significant than the one used in the 2008 financial crisis. The health crisis only made a situation that was already bad worse.

The risk of this crisis affecting the world system is much more serious in 2020 than it was in 1979, 1987 or 2008. The risk is higher of contamination in the derivatives market, which involves trillions of dollars. It is a true fable of money applied to unsupported papers, financial investments completely detached from the real sphere of the economy.

The prospect of a major international crisis, accelerated by a brutal pandemic, is driving all governments to take drastic action, worldwide. Not only in the fiscal, tax and credit fields, but in areas directly linked to disease control. For example, in Spain the government has determined that the country's state health authorities take control of private hospitals, to care for and hospitalize patients with coronavirus. According to the Spanish Minister of Health, the measure aims to guarantee health and public interest by all means and allow citizens to be treated on an equal basis. The Spanish Ministry of Health has also determined that companies and private laboratories that make diagnoses or produce masks and other tools that can be used to fight the coronavirus, must inform the government of their existence and their productive capacity within 48 hours.

The crisis is so serious that a general escape clause from the Stability and Growth Pact (PEC) was activated for the first time. With the decision, the 19 eurozone countries will be able to inject into their economies "everything that needs resources". The PEC, now suspended, limits the public deficit to $3 \%$ and the public debt to $60 \%$ of GDP, under penalty of economic sanctions. With the activation of the clause, countries may have a high deficit and contract public debt above $60 \%$ of GDP.

On the same day 20.02, the British government announced a new stimulus package for the UK economy to face the crisis resulting from the disease. It will be over 38 billion pounds (more than R \$223 billion). These funds will be used to guarantee the payment of $80 \%$ of the wages of the country's workers for a period of three months, starting from the 1st. March. With this, there are already three packages of measures in less than two weeks, totaling 418 billion pounds, or R \$ 2.5 trillion. We are talking about an amount equivalent to $34 \%$ of the Brazilian GDP for measures to contain the economic and health crises. Never in the history of the British State has an encouraging the economy of this magnitude, which gives us 
an idea of the size of the tsunami that is arming on the horizon. Salary guarantees are initially for three months between March and May. But if the crisis deepens, the deadline can be extended. The British government says there are no limits to the amount you want to spend.

In England, in addition to the payment of $80 \%$ of wages, (which will mean spending 8 billion pounds, almost R \$ 47 billion), there will also be a suspension of VAT (Value Added Tax). This tax waiver, to stimulate the functioning of trade, will represent a loss of revenue of around $£ 30$ billion (more than $\mathrm{R} \$ 176$ billion). It is a value equivalent to $1.5 \%$ English GDP. The package also includes help for renters of real estate, at $30 \%$ of the rent. In addition, all business in the hotel and restaurant industry has had government fees suspended to ensure their survival.

The pandemic according to the ILO, in the most moderate forecast could increase the number of unemployed in the world by 5.3 million. In the worst case scenario, it is possible that the number of unemployed will grow by 24.7 million, in a universe, according to the Organization, of 188 million unemployed in 2019. Under ILO forecast, underemployment will also increase, with the inevitable reductions in working hours and wages. The Organization released a calculation of the loss of income by workers, with the crisis, which is expected to be between US $\$ 860$ billion and US $\$ 3.4$ trillion by the end of this year.

In 2009, the decline in world production and trade was halted by the huge investments in infrastructure made by China. In 2020, this no longer occurs and there is no tendency for it to happen, due to the attacks that the country suffers to play that same role. The relatively cooperative interstate regime of 2008-2009, which saw the creation of the G20, gave way to intense commercial rivalry and a great increase in protectionism, caused mainly by the Donald Trump administration.

In 2008, the so-called emerging economies largely escaped the financial crisis of 2008 and recovered in 2009. Now they have been hit immediately. This was the case in Brazil. In 1929, the world economy was internationalized, but not globalized. It took more than a year for the crisis to reach Europe. In 2020, it only took a few weeks for the production stoppage in China to turn into a global crisis.

As the French thinker Chesne recently pointed out in 1929, capitalism was still expanding in the 1930s and would experience, from the beginning of the 1940s, a long cycle of accumulation (Kondratiev cycle), driven, in large part, by technology, but also for the task of completing the worldwide expansion of capitalist production relations. Today, world capitalism is facing a wall. He is being confronted by its social and economic consequences, by global warming and by the dominant technologies due to artificial intelligence.

Production process technology is dominated by robotics, which dramatically reduces the need for labor in many industries and service sectors. As for the technology materialized in the products, its ability to serve as a driver for the resumption of accumulation depends on the importance of the investments that its use implies. This is true both in relation to the industrial branches where they are born and in adjacent activities. They also depend on the expansion of demand created by their social use. With regard to reorganization, all that can be said with certainty is that China's importance in the world will increase. The process of expanded reproduction of capital faces a wall that is linked to the characteristics of technology presented above and to the negative consequences, even for the accumulation, of climate change.

\section{And Brazil?}

Whoever holds power, as has always happened in all major crises in Brazil, is taking advantage of the current crisis to put an end to the rights of workers. For example, in early April PL 9236/17 was approved, which provides for the payment of emergency aid to the poorest in the amount of $\mathrm{R} \$ 600$ per month (for three months for low-income people affected by the health crisis). In addition to the negotiated value being very low (a food basket, with 13 essential products for one person in March/2020, cost an average of R $\$ 517.00$ in Florianópolis), the benefit has not reached the hands of today. part of the people in need. In all regions of Brazil, thousands of workers report that they are unable to withdraw their funds due to bureaucratic requirements.

The important detail is that, due to the technology conditions existing today, and due to the existence of the Federal Government's Unique Registry for Social Programs, set up by the governments prior to the 2016 coup, the benefit could start to be paid on the same day of the PL's approval in the National Congress. From a practical point of view, given the importance of the benefit, it would justify placing even the Armed Forces and Auxiliary Forces, to immediately make the arrival of the resource in the pocket of those who are already starving. Not doing so is clearly an option of the government, which is concerned with spending as little as possible on the poor, with a view to leaving more resources for the rich in general.

While the population is concentrating on facing the pandemic, and much of it struggles to put food on the table, they take the opportunity to make the workers pay the bill for the crisis, alone. An example of how 
wealthy elites in Brazil treat the population. The Public Ministry of the State of Mato Grosso, in April, instituted a "Bonus covid" of up to R \$1,000 for prosecutors, prosecutors and civil servants to use in health expenses during the pandemic. The measure, from May 4, 2020, will cost R \$ 680 thousand per month. Attorneys and prosecutors are entitled to $\mathrm{R} \$ 1,000$ and the other civil servants to $\mathrm{R} \$ 500$. The administrative act of the Public Prosecutor of Mato Grosso comes at a time when the population gets angry at the Caixa Econômica Federal lines trying to withdraw the miserable $\mathrm{R} \$ 600,00$, so as not to starve.

A second example of the "consideration" with which the people in Brazil are treated. On the 6th, the Chamber of Deputies approved, in a second round, the Proposed Amendment to the Constitution (PEC) 10/2020, which allows the Central Bank (BC) to acquire rotten papers from large banks and investors, without any limit on the amount. Experts who follow the matter closely say that the PEC will increase the public debt by several trillion reais. While the government proposes to allocate $\mathrm{R} \$ 200$ reais per month to the unemployed and helpless (the $\mathrm{R} \$ 600.00$ came through negotiation, based on a proposal of R $1,000.00$ from the opposition), they approve a PEC that will increase the debt exponentially which, in the end, will be paid by the population.

The large business community feels so at ease, in a country where half the population is dependent on R\$ 600.00 in Emergency Income to avoid starving, that sometimes some of them have attacks of "inconvenient sincerity": Guilherme Benchimol, president and founder of XP Investimentos, recently stated that Brazil is going the right way and has already overcome the coronavirus in the upper and middle classes. He said in an interview: "Following our numbers a little, I would say that Brazil is doing well. Our curves are not as exponential yet, we have been able to flatten them. We will have a clearer picture in the next two to three weeks. The peak of the disease has passed when we analyze the middle class, upper middle class". On the other hand, there is a real deluge of international capital that escapes Brazil. The net outflow of dollars from the Brazilian economy last year (inflows less outflows) was US \$ 44.77 billion, the largest foreign exchange evasion in Brazil in the entire historical series, which started in 1982. But this year alone, the values have practically fled observed throughout the past year. The big "investors" have a great thirst for profits and long legs. They also have privileged information, which we, mere salespeople of the workforce, do not have access to. The previous record of capital flight had been set in 1999, when the foreign exchange balance (difference between dollar inflows and outflows) was negative at US \$ 16.18 billion. In March alone, the Central Bank already injected US \$ 15.245 billion in new resources in the foreign exchange market, trying to contain the dollar's escalation. Even so, the real is the currency that has devalued the most in the world this year.

\section{Final considerations}

From the diagnosis made, it is possible to project some general trends in the evolution of the world economy, as follows:

\section{Increase in indebtedness and defaults}

Unlike 2007/2009, now, in 2020, there is a weakness in the monetary tools that were so important in September 2008; the loss of effectiveness of central bank interventions and the already high level of public debt at the beginning of the pandemic. The response to the covid-19 crisis requires an increase in countries' fiscal deficits of around 10\% of GDP or more. And that happens at a time when public debt levels in many countries were already high, if not unsustainable. The loss of income for many families and businesses can generate massive defaults.

In Brazil, the situation will be worse: the Chamber of Deputies recently approved, in a second round, the Proposed Amendment to the Constitution (PEC) 10/2020, which allows the Central Bank (BC) to acquire rotten papers from large banks and investors, without any limit. These are papers that have been accumulated for 15 years, and that will mean a loss to the public treasury of trillions of reais! While the population is distracted, trying to survive the coronavirus and hunger, they take the opportunity to pluck the public purse.

\section{Need for greater investments in health systems}

The coronavirus crisis showed the failure of countries that destroyed their public health systems during decades of neoliberal policies. The importance of allocating greater expenditures to public health systems is evident. The consequence is that the "financing" of these eventual health expenditures will further increase the implicit debts of the current health care and social security systems, since the economically active (and taxpaying) population is getting smaller compared to the population that needs assistance (the elderly). 


\section{Risk of deflation}

The coronavirus crisis is also creating a "slack" in the production of goods and creating unemployment (in addition to causing a collapse in the prices of commodities, such as oil and industrial metals, whose demand has decreased dramatically). This makes price deflation generally likely. The population has no income to consume the products and therefore their prices fall. But the phenomenon generates mass unemployment and poverty. Deflation means that the patient is weakened, the economy is losing its vital signs.

\section{Crisis in the labor market}

Millions of people are losing their jobs or having their income reduced, the differences in "income" and "wealth" of the 21 st century economy will widen further. Firms in advanced economies will transfer production from low-cost regions to high-cost domestic markets in order to protect themselves from potential risks. But in this case, this trend will accelerate the pace of automation, pushing down wages, further increasing xenophobia.

\section{5. "Deglobalization"}

The pandemic is accelerating trends in deglobalization, according to economist Noriel Roubini. The United States and China will dissociate more quickly, and most countries will respond by adopting even more protectionist policies to protect companies and domestic workers from global disruptions.

As Roubini says, the post-pandemic world "will be marked by stricter restrictions on the movement of goods, services, capital, labor, technology, data and information".

\section{Immigration and trade restrictions tend to increase}

Under conditions of greater economic insecurity, there will be a strong scapegoat for foreigners and trade for the crisis.

\section{Tensions between US and China increase}

With the Trump administration making every effort to blame China for the pandemic. The dispute between countries in trade, technology, investment, data and monetary agreements will intensify, contaminating the world. If it depended on the US stance, the dispute would quickly turn into war.

\section{References}

GUIMARÃES, Samuel Pinheiro. Estados Unidos \& China: duas estratégias na luta pela hegemonia. Disponível em: https:/ /outraspalavras.net/geopoliticaeguerra/Estados Unidos-china-duas-estrategias-na-luta-pela-hegemonia/. Acesso em: 10 maio 2020.

MOURA, J. Pico de Covid-19 nas classes altas já passou; o desafio é que o Brasil tem muita favela, diz presidente da XP. Disponível em: https://www1.folha.uol.com.br/mercado/2020/05/brasil-esta-indo-bem-no-controle-do-coronavirus-e-pico-nas-classes-altas-japassou-diz-presidente-da-xp.shtml. Acesso em: 07 maio 2020.

MINEIRO, Adhemar. A crise internacional do coronavírus: uma conjuntura difícil no curto-prazo, e de mudanças importantes no médio e no longo prazo. 2020. Disponível em https://www.uscs.edu.br/boletim/5732.pdf. Acesso em: 10 maio 2020.

RUSSO JÚNIOR, Carlos. 40 milhões de miseráveis: the new yorker expõe face oculta e cruel dos estados unidos. Diálogos do Sul, 14 abr. 2020. Disponível em: https://dialogosdosul.operamundi.uol.com.br/permalink/64142. Acesso em: 10 maio 2020.

\section{Note}

1 Article published on February 14, 20, in the journal Science, and reflected on Brazilian information sites.

2 Basic Scenario of the Fund, released in April / 2020.

3 Mineiro, Adhemar: The international coronavirus crisis: a difficult situation in the short term, and major changes in the medium and long term. May 2020

4 Russo Júnior (2020).

5 Vietnam is also today an example to the world of how to face the pandemic. With almost 96 million inhabitants and occupying an area slightly larger than that of Goiás, until 30.05.20 it had not registered a single death of covid-19 among the 328 infected, of which 279 were already cured. Social isolation ended on April 22, although restrictive measures are maintained for bars, clubs, spas, theaters, sports centers. Meetings with more than 20 people are prohibited, and restaurants and cafeterias must obey the guidelines of local authorities. The country, which borders on China, had already acquired experience on how to deal with other types of coronavirus, such as SARS (2002) and MERS (2012). 


\section{José Álvaro de Lima Cardoso}

$\mathrm{PhD}$ in Human Sciences from the Federal University of Santa Catarina (UFSC)

Economist and Technical Supervisor of the Inter-Union Department of Statistics and Socio-Economic Studies, Regional Office of Santa Catarina (DIEESE)

\section{DIEESE}

Avenida Mauro Ramos, 1624 - Centro

Florianópolis - Santa Catarina - Brasil

CEP 88020-302

\section{Acknowledgement}

Not applicable.

Financial support

Not applicable.

Contributions of authors

Not applicable.
Approval by the Ethical Committee and consent to participate

Not applicable.

\section{Consent to publish}

Consent author.

Conflict of interest

Not applicable. 